\title{
Internal Control As A Potential Instrument For Corporate Governance
}

\author{
Atu, Oghogho Gina; Dr. Raph Adeghe; Atu,Omimi-Ejoor Osaretin Kingsley \\ Post Graduate Student, Igbinedion University, Okada Lecturer - Department Of Accounting Veritas University, \\ Abuja (The Catholic University Of Nigeria) Nigeria-West Africa. \\ Dean, College Of Business And Management Studies Igbinedion University, Okada. Edo State, Nigeria-West \\ Africa. \\ (Aca,Fcma,Acti,Aat, M.Sc(Accounting), M.Sc(Business), Mba(Accounting)Pdg (Comp.Sc); Dipl.Ph.D In View) \\ Lecturer - Department Of Accounting Igbinedion University, Okada. Edo State, Nigeria-West Africa.
}

\begin{abstract}
Recent scandals in the business world have pushed the concept of corporate governance to the limelight. Internal audit with a clear mandate from the institute of internal auditors has a crucial role to play in organization's corporate governance. To succeed, an organization's governance needs to rest on four pillars represented by the board of directors, management, internal audit and external audit. Each pillar must be effective and work well together to support the achievement of organizational goals and objectives. Out of the pillars listed above three of which has being dealt with in this research with more emphasis on internal audit and board of directors contribution to corporate governance. Via an extended literature review, the results indicate that internal auditing plays a vital role in effective corporate governance.
\end{abstract}

Key words: internal audit, board of directors, corporate governance

\section{Introduction}

The recent corporate scandals which shook the business world involving Enron, Parmalat, Cadbury Nigeria and other notable companies have fixed a spotlight on accounting failures have pointed out the need for substantive improvement in corporate governance and accounting information which provides critical decision influencing and decision facilitating information for control.

Bad corporate governance in Nigeria has caused the downfall of most firms, these underscores the importance of effective corporate governance procedures to the survival of the micro economy. This means that "even strong economics, lacking transparent control, responsible corporate boards, and shareholders right can collapse quite quickly as investor's confidence collapse".

In Malaysia, the collapse of the Asian tiger in 1997 was as a result of lack of corporate governance. Compliance to corporate governance by firms is of outmost priority as its neglect can be very disastrous.

A good system of corporate governance ensures that responsible persons carry out their duties within a framework of accountability and transparency. The benefit is that the overall efficiency and competiveness of the economy will be enhanced thereby boosting the confidence in economy. INTERNAL auditing is an integral part of the corporate governance mosaic in both the public and the private sectors (Cohen, Krishnamoorthy, \& Wright, 2002) this is because an effective organization is one that has good and valuable internal control that could check problem areas in the organization so that remedial action could be taken. Internal checks and balances, are also known as internal control, is an essential element of sound management. It ensures that senior management has the problem and takes remedial actions as soon as possible. Onochie (2005). However, despite the campaign awareness of corporate governance as a whole there are still records of corporate failures and as such recent events have highlighted the critical role of the boards of directors in promoting good corporate governance which can only be achieved through effective internal control functions. Therefore, framework of modern business world, the role of an internal control system is catalytic since it is regarded as a source from which core abilities are given or drawn and are subsequently transformed into competitive advantages (drogalas, pantelidis, vouroutzidou \& Kesisi; 2011). This is to sum it up that internal control is important for effective corporate governance in modern business environment. Thus the purpose of this study is to establish internal control as a potential instrument for corporate governance. From the above it is impotent that the need to study the importance of internal audit in corporate governance is justifiable and the researcher is not aware of any study carried out in Nigeria which has dealt with the issue of corporate governance and internal audit, hence the researcher contribution to knowledge.

\section{Literature Review}

There is no one universal definition of internal control as each author has their own insight as to what is internal control. In 1992, The Committee of Sponsoring Organization of the Treadway Committee ("COSO") defines internal control as a process designed to provide reasonable assurance regarding the achievement of business objectives. The Chartered Institute of Public Finance and Accountancy (CIPFA), as cited by Johnson 
(1996:47), defined internal audit as "an independent appraisal function within an organization for the review of activities as a service to all levels of management. It is a control which measures, evaluates and reports upon the effectiveness of internal control, financial and otherwise, as a contribution to the efficient use of resources within an organization." While Okoye (1997). Defines it As the actions taken by the management to ensure that staffs conform with the plans as much as possible.

An important step was the new definition of Internal auditing issued by the IIA in June 1999, which clearly states that "the internal auditing activity should evaluate and contribute to the improvement of risk management, control and governance" (IIA, 1999). The new definition shifts the focus of the internal audit function from one of assurance to that of value added and attempts to move the profession toward a standardsdriven approach with a heightened identity (Bou-Raad, 2000; Krogstad, Ridley \& Rittenberg, 1999).

More recently, the Institute of Internal Auditors (2004) by stating that the internal audit activity should evaluate and contribute to the improvement of risk management, control and governance, recognizes the assurance and consulting role of internal auditing in corporate governance. The Internal Control moves within a greater scope of management philosophy and of practical application, and adds up value, offering at the same time a systematic In the views of Oladipupo (2005) internal control is a process within an organization designed to provide reasonable assurance regarding the achievement of the organizational objective. By internal control we mean not only internal check and internal audit. Is a whole system of controls, financial or otherwise, established by management in order to carry out business of the organization in an orderly manner, safeguard its assets and to secure as far as possible the accuracy and reliability of its records. However the most detailed definition of internal control was that given by Millichamp (2002) who said and I quote that internal audit is "the world system of controls, financial and otherwise, established by the management in order to carry on the business of the enterprise in an orderly and efficient manner, ensure adherence to management policies, safeguard the assets and secure as far as possible the completeness and accuracy of the records". He didn't just stop there but he went further to give an in-depth insight of the definition by picking each keyword of the definition and expatiating on it.

The whole system: Under this, he explains "internal controls can be seen as a single procedure e.g. clerk a checks the calculations performed by clerks B or as whole system. The whole system should be more than sum of the parts.

Financial and otherwise: The distinction is not perhaps financial would include the use of control accounts and otherwise may include physical access restriction to computer internals.

Established by the management. The management established internal control systems, directly or by means of external consultants, internal audit, or accounting personnel. External auditors may be asked to advice on the setting up of systems.

Carry on.... Efficient manner. Clearly the converse is unacceptable in any business.

Ensure adherence to management policies. Not all management has expressed policies. But as an example, a budget is an expression of management policy and adherence to the budget can be achieved by procedures such as variance analysis. Another example might be setting the selling prices of the enterprise's products being laid down by management and controls existing to ensure that these prices are adhered to.

Safeguard the asset. Obviously allowing assets to be broken. Lost or stolen is unacceptable and procedures are always devised to safeguard them. Examples are: locks and keys, the keeping or of plant register, regular review of debit balances etc. an aspect of this which is often overlooked is the part where no benefits have been received, as payment for piece of work not done, or setting up of liabilities where no benefits has been receivedas in fraudulent purchase and subsequence embezzlement of goods by employees are both examples of failure of safeguard assets.

Secure...... Completeness. It is especially important that all transactions are recorded and processed. Procedures which do this include checks that no goods leave the factory without a delivery note followed by regular comparison of involve.

And accuracy of the records. Again, the converse is unacceptable. Examples of procedures to achieve this include checking of the work of one clerk by another or the use of control accounts. Independent comparison of two sets of records. E.g. stock record, and stocks (actually present), or piecework payments and good work put into store".

internal auditing can also be seen as is a systematic, objective appraisal by internal auditors of the diverse operations and controls within an organization to determine whether (1) financial and operating information is accurate and reliable, (2) risks to the enterprise are identified and minimized, (3) external regulations and acceptable internal policies and procedures are followed, (4) satisfactory operating criteria are met, (5) resources are used efficiently and economically and (6) the organization 's objectives are effectively achieved - all for the purpose of consulting with management and for assisting members of the organization in the effective discharge of their governance responsibilities". Sawyer (2003). This definition shows that the role of internal audit has been dramatically shifted from compliance assurance and assets safeguarding to value-added assurance and 
consulting services through its role in monitoring, evaluating, and improving risk management, control, and governance process which are critical to preserving and enhancing stakeholders value

From the above, the importance of internal control in an organization can not be overemphasized. The main objectives of an effective internal control system according to Public Accountants (AICPA) (2003) include;

Effectiveness and efficiency of operations: This objective addressed an entity's basic business objectives, including performance and profitability goals and safeguarding of resources

Reliability of financial reporting: This relates to preparation of reliable and condensed financial statements and select the financial data derived from such statements, such as earnings released, reported publicly.

Compliance with applicable laws and regulations: This entails complying with those laws and regulations to which the entity is a subject

\section{Responsibilities of internal control}

Everyone in the organization has a responsibility in the internal control structure. The COSO designates each party's role and responsibility as follows:

Management - the Chief Executive Officer / General Manager is ultimately responsible and should assume "ownership" of the system.

Audit committee - management is accountable to the audit committee which provides governance, guidance and oversight.

Internal auditors - internal auditors play an important role in evaluating the effectiveness of control systems and contribute to ongoing effectiveness. The internal audit function also plays a significant monitoring role.

Other personnel - internal control is, to some degree, the responsibility of everyone in an organisation and therefore should be part of each person's job description. Virtually all employees produce information used in the internal control system or take other actions needed to effect control. All personnel should be responsible for communicating problems in operations, noncompliance with the code of conduct, policy violations or illegal acts.

\section{Review Of Related Literatures}

The first study in this area was that of Paape, Scheffe, \& Snoep, (2003), they explores the relationship between internal audit and corporate governance. Data were collected from the largest companies of 15 European Union countries, a total of 332 questionnaires were sent, of which one hundred and five were answered. The result of the research is the differences during internal auditors work and the perception of the role of internal auditors to corporate governance by country. Hence, it is a fact that there is lack of internal audit and audit committee on 50 companies and business managers are unaware of the recommendations and regulations on corporate governance. Finally, compliance with regulations and procedures viewed as the main purpose of internal audit, while the implementation of operational controls is considered as the main contributor of internal control. Goodwin (2003) Researched on the relationship between audit committee and internal audit. Out of the 370 Questionnaire addressed to internal auditors of financial institutions (public and private sectors) from Australia and New Zealand, who were members of the Institute of Internal Auditors 120 responses were received, it was concluded based on the research that independence and accounting experience have a complementary impact on audit committee relations with internal audit. Leung, Cooper, \& Robertson, (2004), investigated the role of internal audit in corporate governance in Australia. Questionnaires were sent to internal auditors and directors of Australian financial institutions. The main output from their research was the fact that the culture and the support of the Board of Directors are key factors that directly affects internal audit's effectiveness. Also Gramling, Maletta, Schneider, \& Church, (2004) examined the relationship between internal audit and corporate governance. The most important finding of this study was the catalytic role of internal auditing in the effective corporate governance. Karagiorgos, Drogalas, Gotzamanis \& Tampakoudis (2010) examine in a theoretical level the contribution of internal auditing to corporate governance and the interaction between various corporate governance factors, such as the board of directors, the audit committee and the external auditor, and the internal audit process. The results of this literature review indicate that internal auditing plays a vital role in effective corporate governance.

More recently, Ibrahim El-Sayed Ebaid (2011) explore the nature and characteristics of internal audit function in Egyptian listed firms and assess its ability to fulfill its role in corporate governance. The study was carried out through a questionnaire survey. The results showed that internal audit function in Egyptian listed firms, in its current status, faces many difficulties that affect negatively its effectiveness in corporate governance. Therefore, extensive efforts should be made to enhancing the internal audit profession in Egypt. 
Finally, Drogalas, Pantelidis, Vouroutzidou \& Kesisi (2011) Examines the relationship between internal audit and corporate governance in Greece. According to up-to-date theoretical and empirical literature, the results point out the factors that assess the interaction between internal audit and corporate governance.

\section{INTERNAL CONTROL AND CORPORATE GOVERNANCE}

Due to recent events it has being generally accepted that the correlation between internal auditing and corporate governance affects all kinds of economic activities and as such the Board of Directors has been recognized as the key player in corporate governance by regulators and governance committees around the world (US Congress, 2002; ASX, 2003). This was not just because the board plays an important role in internal control but also because of the fact that the Board of Directors is ultimately responsible for the entity's accomplishment of its objectives, the internal auditor's contribution is to providing information to that group (Colbert, 2002). The new definition given by the Institute of Internal Auditors (2004) by stating that the internal audit activity should evaluate and contribute to the improvement of risk management, control and governance, recognizes the assurance and consulting role of internal auditing in corporate governance has moved internal audit from its traditional view to focus more on board of directors which is an element of corporate governance the board of directors holding comprehensive power over management performs the following functions which aids corporate governance: (1) setting business goals and strategies, (2) approves business plan and budgets, (3) supervising management and evaluating their performance, (3) monitoring the effectiveness of governance practices, (4) overseeing the process of information disclosure and risk management (5) lastly ensure the integrity of accounting and financial reporting practice by supervising the compliance with statutes and professional ethnics. Apart from the above, internal audit's role is crucial to assisting the Board of Directors in its governance self-assessment. According to Cook and Wincle (1976), the Internal Control System resembles the human nervous system which is spread throughout the business carrying orders and reactions to and from the management. In this concept, by measuring and evaluating the effectiveness of organizational controls, internal auditing, itself, is an important managerial control device (Carmichael, Willingham \& Schaller 1996), which is directly linked to the organizational structure and the general rules of the business (Cai, 1997). Internal auditing contribute to corporate governance by:

- Bringing best practice ideas about internal controls and risk management processes to the audit committee.

- Providing information about any fraudulent activities or irregularities

(Rezaee \& Lander, 1993)

- Conducting annual audits and reporting the results to the audit committee.

- Encouraging audit committee to conduct periodic reviews of its activities and practises compared with current best practises to ensure that its activities are constituent with leading practises (Sawyer, 2003).

External audit is also regarded as an important cornerstone of corporate governance, particularly with respect to the prevention and detection of fraud and errors in financial statements (Adamec, Leinicke, Ostrosky \& Rexford, 2005; Davidson, Goodwin-Stewart \& Kent, 2005).

The relationship between internal and external auditors should be one of mutual support and cooperation in order to strengthen overall audit quality and mechanisms of corporate governance (Gramling and Myers, 2003 as cited in Karagiorgos et al, 2010). Finally internal auditing help corporate governance by reviewing the organization's code of conduct and ethics policies to ensure they are current and are communicated to employees and Internal audit activity may lead to the strengthening of internal control as a result of management response by assisting management in the pursuit of value for money. This is achieved through economic, efficient and effective use of resources.

\section{Summary And Conclusion}

For an organization's governance process to succeed it must have an effective internal control this is because of the inherent benefits of internal control and audit. Internal audit is an evolving area in accounting and business world and its has yet to be developed into its full flesh self hence research in this area. The researchers do not intend to draw conclusion on this issues as it is relatively a new area. However the researcher establish internal control as a potential instrument for corporate governance in relation to board of directors. The main limitation of this study is that it is not focused on any specific industry sector or organizational size to any great extent and also the study is purely theoretical. Therefore, it is recommended further research to take a more focused approach by examining the matters reported in this paper empirically in differentareas of industry sectors and organisational size, other elements/ instruments of corporate governance which researcher can research into and determine the most correlated instruments. Realization of the major importance of internal audit in efficient management will set internal audit as a priceless support in the business management effort. other elements/ instruments of corporate governance which researcher can research into and determine their correlation. 


\section{References}

[1]. Adamec, B. A., Leinicke, L. M., Ostrosky, J. A. \& Rexford, W. M. (2005), Getting a Leg Up. Internal Auditor, 62 (3)

[2]. ASX (2003), Principles of Good Corporate Governance and Best Practice Recommendations, Australian Stock Exchange Corporate Governance Council, Sydney.

[3]. Bou-Raad, G. (2000), Internal Auditors and a Value-added Approach: The New Business Regime”, Managerial Auditing Journal, 15 (4).

[4]. Cai, Chun (1997), On the Functions and Objectives of Internal Audit and their Underlying Conditions. Managerial Auditing Journal, 12 (4)

[5]. Carmichael, D. R., Willingham, J. J., and Schaller C. A. (1996), Auditing ConceptsAnd Methods. A Guide to Current Theory and Practice (6th ed). McGraw-Hill.

[6]. Cohen, J., Krishnamoorthy, G. and Wright, A. (2002), Corporate Governance and the Audit Process. Contemporary Accounting Research, 19 (4)

[7]. Colbert, J. (2002), Corporate Governance: Communications from Internal and External Auditors. Managerial Auditing Journal, 17 (3).

[8]. Committee of Sponsoring Organizations of the Treadway Commission (COSO) (1992), "Internal Control-integrated Framework", Coopers and Lybrand.

[9]. Davidson, R., Goodwin-Stewart, J. \& Kent, P. (2005), Internal Governance Structures And Earnings Management, Journal Accounting and Finance, 45 (2).

[10]. Gramling, A. A. \& Myers, P. M. (2003), Internal Auditors' Assessment of Fraud Warning Signs: Implications for External Auditors. The CPA Journal, 73 (6).

[11]. Institute of Internal Auditors (1999) Definition of Internal Auditing, The Institute of Internal Auditors, Altamonte Springs, FL

[12]. Institute of Internal Auditors (2004), "International Standards for the Professional Practice of Internal Auditing", available at: www.theiia.org/?doc id=1499.

[13]. Krogstad, J., Ridley, A., \& Rittenberg, L. (1999), Where we're Going. Internal Auditor,12.

[14]. Sawyer B. Lawrence (2003), Sawyer's Internal Auditing: The Practise of Modern Internal Auditing. The Institute of Internal Auditors, 5th Ed.

[15]. United States Congress (2002), "The Sarbanes-Oxley Act of 2002", Paper Presented at $107^{\text {th }}$ Congress of the United States of America, H.R. 3763, Government Printing Office,Washington, DC

[16]. Karagiorgos .T. Drogalas .G; Gotzamanis .E. \& Tampakoudis. L. (2010) Internal Auditing As an Effective Tool For Corporate Governance. Journal of Business Management 2 (1). Industrial Science Press Gramling, A.A., Maletta, M.J., Schneider, A. \& Church, B.K. (2004) The Role of the Internal

[17]. audit Function in Corporate Governance: a Synthesis of the Extant Internal Auditing Literature and Directions for Future Research. Journal of Accounting Literature, 23

[18]. Goodwin, J. (2003) The Relationship between the Audit Committee and the Internal Audit Function: Evidence from Australia and New Zealand. International Journal of Auditing, (7)3. Ibrahim El-Sayed Ebaid, (2011) Corporate Governance Practices and Auditor's Client Acceptance Decision: Empirical Evidence from Egypt. Corporate Governance, 11 (2).

[19]. Leung, P., Cooper, B.J. \& Robertson, P. (2004) The Role of Internal Audit in Corporate Governance and Management. RMIT Publishing: Melbourne.

[20]. Paape, L., Scheffe, J. \& Snoep, P. (2003) The Relationship between the Internal Audit Function and Corporate Governance in the EU - a Survey. International Journal of Auditing, 7

[21]. Malaysian Institute of Accountants (2004). Internal Audit Guidelines. Retrieved June 12, 2006 from the World Wide Web: http//www.mia.or.my/handbook/guide/IAG.htm.

[22]. Millichamp A.H. (2002). Auditing ( $8^{\text {th }}$ Ed.). The Bath Press: London.

[23]. Oladipupo, A. (2003). Principle and Practice of Auditing. Mindex Press: Benin Okoye A.E. (1997). Cost Accountancy. Benin United City Press. Benin City Nigeria.

[24]. Onochie. V. ( 2005) Auditing and investigation. Vindo associates limited: Lagos, Nigeria Johnson, I. E. (1996), Public Sector Accounting and Financial Control. ( $2^{\text {nd }}$ Ed.)Financial Training Nigeria: Surulere

[25]. Drogalas .G. Pantelidis .P, Vouroutzidou .R. \& Kesisi .E.(2011) Assessment of Corporate Governance via Internal Audit

[26]. Rezaee, Z. \& Lander, G. (1993), The Internal Auditor's Relationship with the Audit Committee. Managerial Auditing Journal, MCB University Press, 8 (3). 